\title{
COMBAT CLIMATE CHANGE CHALLENGES IN CONSIDERING CLIMATIC VULNERABILITIES AND RISK FACTORS FOR WHEAT PRODUCTION
}

\author{
M. M. Rahman ${ }^{* 1}$, M. G. Miah ${ }^{2}$ and S. R. Saha ${ }^{2}$ \\ ${ }^{1}$ Deputy Secretary, Ministry of Environment and Forests, Government of the People's \\ Republic of Bangladesh, Bangladesh Secretariat, Dhaka-1000 \\ ${ }^{2}$ Department of Agro-forestry and Environment, Bangabandhu Sheikh Mujibur Rahman \\ Agricultural University (BSMRAU), Gazipur
}

\begin{abstract}
The present study was undertaken for assessing the impacts of climate variability on wheat production as well as the field based suggestions opined by the wheat growers to combat the future challenges particularly climate variability during November 2014 to March 2015. The study was conducted at northwest region at Dinajpur sadar and Kaharul upazilas in Dinajpur of Bangladesh. One hundred sixty wheat farmers were selected by using previously pre-tested interview schedules adopting multistage proportionate systematic random sampling technique. Climatic variability was assessed by analysis of long term data of local meteorological station. Assessment of long term climatic data particularly for wheat growing season revealed that minimum temperature has been increased, while maximum temperature and rainfall were decreased. Farmer's opinions on these aspects were almost similar. Farmers opined that both surface and ground water levels have been decreased, resulting agricultural drought. Farmer's also opined regarding suitable technology to combat climate change impact on wheat production revealed the use of newly recommended varieties. Finally, the outcome of the results could help researchers as well as government and NGOs to take appropriate climate change adaptation policy thus facilitating farmers in sustaining their livelihoods against changing climate in the near future of Northwest region in Bangladesh.
\end{abstract}

Keywords: Climate variability, rainfall, drought, surface and ground water availability, wheat cultivation, and northwest region of Bangladesh

\footnotetext{
* Corresponding author email: rahman.masumur@gmail.com
} 


\section{INTRODUCTION}

Climate change is a potential threat towards achieving increasing major crops production under sustainable environmental conditions (Basak et al., 2009). Climatic information are not only important for recommending the most suitable time for sowing and harvesting but also acts as a guide to the selection of proper sites for a certain crop (Amin et al., 2004). Some of the studies have demonstrated that agricultural activities in developing countries are extremely vulnerable to climate change which is more applicable under Bangladesh perspective.

Hence, it is important to examine the impact of climate change on wheat yields with an evaluation of existing responses by farmers to climate change (GOB, 2009). However, some periodic studies has investigated at the farm level to seek farmers' perception and adaptation options towards climate change impacts on wheat. The effects of climate change on crop production are global concerns, but these are particularly very important for the sustainable agricultural development of Bangladesh (Hossain and Da Silva, 2013). This is because of variant climatic conditions of the country due to its' geographic position and physiographic status have made Bangladesh a meeting point of the life-long monsoon precipitations and the catastrophic devastation of floods, droughts, cyclones, storm surges, etc. (Ferdous and Batez, 2011). Agriculture plays a significant role in Bangladesh economy, socially and culturally. It accounts for about $18 \%$ of the country's GDP and is a means of livelihood that engages more than $47 \%$ of the labour force (World Bank, 2013). It also supplies food and confer livelihood security for the Bangladeshi people. Over $75 \%$ of agricultural production takes place in rural areas where more than $80 \%$ people are engaged in farming activities and growing crops to meet the basic needs of the people. But this agriculture sector is susceptible to unfavorable weather conditions and climatic events. In spite of noticeable technological progress (such as improved crop varieties and irrigation facilities), weather and climate are still the key determinants for agricultural productivity and sustainability. Bangladesh has been facing steadily increase of higher temperature over the last three decades (Sarker et al., 2012). Moreover, it is forecasted to experience a rise in annual mean temperatures of $1.0^{\circ} \mathrm{C}$ by $2030,1.4^{\circ} \mathrm{C}$ by 2050 and $2.4^{\circ} \mathrm{C}$ by 2100 . The average temperature during winter season (December, January and February) also showed a similar increasing pattern of $1.1^{\circ} \mathrm{C}$ by $2030,1.6^{\circ} \mathrm{C}$ by 2050 and $2.7^{\circ} \mathrm{C}$ by 2100 . The projected values are $0.8^{\circ} \mathrm{C}$ by $2030,1.1^{\circ} \mathrm{C}$ by 2050 and $1.9^{\circ} \mathrm{C}$ by 2100 for the monsoon months (Agrawala et al., 2003; Ahmed, 2006). However, the Global Climate Model (GCM) data estimated more warming for winter than for the summer months (FAO, 2007). Based on the above projections, Bangladesh is likely to face more hot days and heat waves, longer dry spells and higher drought risk. In contrast, almost 80 percent of rainfalls in Bangladesh have been occurring during monsoon season (June-September) and the remaining 20 percent covers eight months, including the winter months. Most of the climate models estimated that precipitation will increase during the summer monsoon (Mirza, 1997; Ahmed 
and Alam, 1998; GOB, 2009). This erratic and unevenly distributed pattern produces extreme events, such as floods and droughts, which have remarkable harmful effects on major food crops' yield, especially on Aman rice. As a result, rice production is likely to decline by $8 \%-17 \%$ by 2050 (Sarker et al., 2012, BBS 2005 and IPCC, 2007). The present food grain production is not sufficient to meet domestic requirements.

It clearly indicates that the deficit of food grains will be a major issue in Bangladesh. This approach help to measure the existing level of different socioeconomic, institutional and physical conditions of the drought affected area and shows the comparison of drought resilience among upazillas. This study, therefore, intends to examine the level of farmers' perception and awareness about climate change, the nature of their impacts, and various adaptation practices to be followed by the farmers with the following objectives as follows;

- To assess the climatic vulnerabilities by analysis of long term meteorological data, and

- To analyze the risk factors in wheat growing areas assessing rainfall, drought, surface and ground water availability at northern region of Bangladesh

\section{METHODOLOGY}

The study was conducted in randomly selected 160 wheat farmers in two upazilas namely, Dinajpur sadar and Kaharul under Dinajpur district of Bangladesh based on highly concentrated wheat growing areas. Demographic characteristics of the farmers, primary, secondary, quantitative and qualitative data were collected during November 2014 to March 2015 based on a pre-designed interview schedule with balanced combination of both closed and open-ended questions, and the same pre-tested before finalization. Participatory Rural Appraisal (PRA) tools and techniques like Focus Group Discussion (FGD), Direct Observation and Case study were also applied for triangulation of data. In order to collect relevant information from the wheat farmers, three sets of instruments (interview schedules) were carefully designed. The selected measured variables were weather and climatic parameters, long-term (1970-2015) climatic data of monthly temperature and rainfall, and adaption to combat climate change effect, etc. The SPSS package was used to perform data analysis. All the collected data were then checked and cross checked, compiled, coded and entered into the computer for analysis and interpretation using this software. Descriptive statistical measures like range, mean, number and percentage distribution, standard deviation were used to describe and interpret the data. Statistical measures like number, range, mean and standard deviation were calculated in describing the selected socio-economic characteristics as well as their livelihood status. 


\section{RESULTS AND DISCUSSION}

The findings of the study and its interpretation have been presented systematically and logically in accordance with the objectives of findings related to risk factor assessment of climate vulnerability.

\section{Changes of climate}

The evidences of climate change over time were documented through analysis of long-term (1970-2015) climatic data of monthly temperature and rainfall.

\section{Trend of temperature}

The findings of the long term temperature data showed an decreasing trend of maximum temperature while increasing trend was noticed in minimum temperature (Figure 1 and 2).

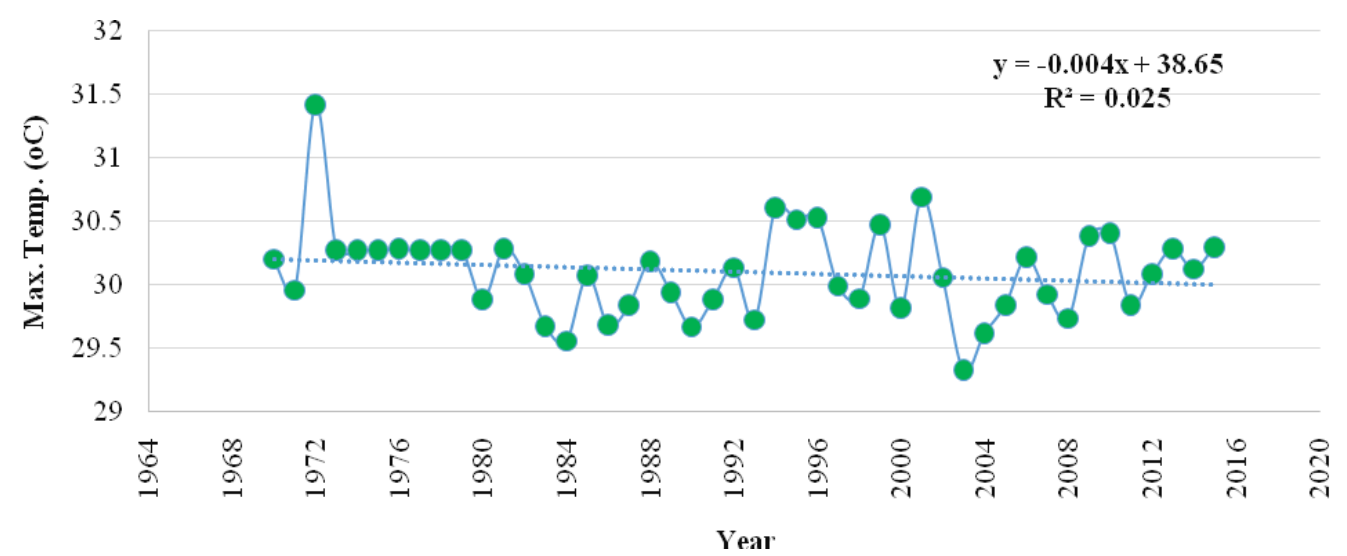

Figure 1. Long term (1970-2015) trend of maximum temperature in the study area

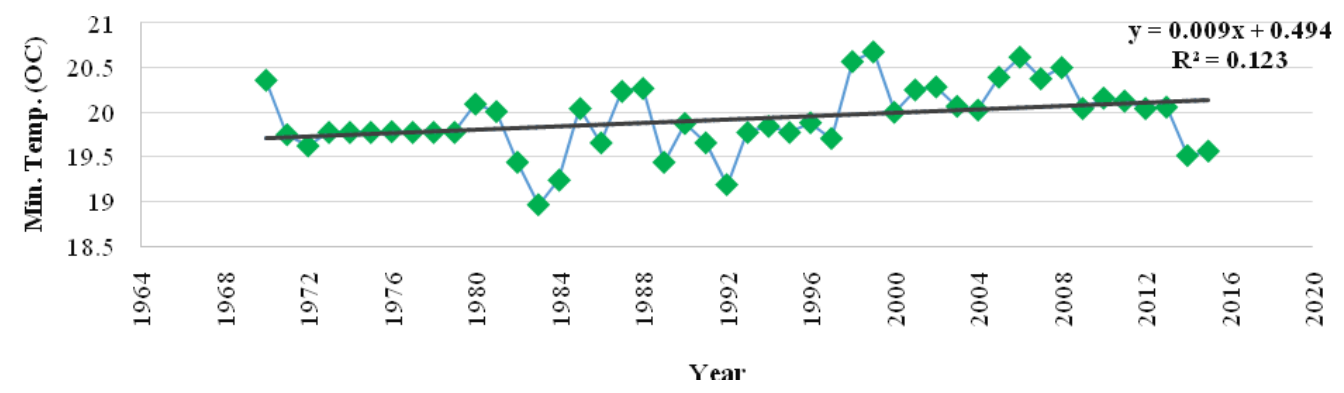

Figure 2. Long term (1970-2015) trend of minimum temperature in the study area

Nevertheless, minimum temperature was increased at the rate of $0.009^{\circ} \mathrm{C}$ whereas, maximum temperature was decreased at $0.004^{\circ} \mathrm{C}$ per year. The maximum temperature $\left(31.42^{\circ} \mathrm{C}\right)$ was observed in 1972 , afterwards temperature sharply declined and continue constantly till 1980. From 1981, maximum temperature showed an arbitrary trend though the temperature found to be higher during 1994 to 
2002 compared to the previous years. Interestingly, in 2003, the least value of maximum temperature $\left(29.32{ }^{\circ} \mathrm{C}\right)$ was noticed which then gradually increased up to 2007 and again showed an irregular increasing trend. For minimum temperature, after 1971, it showed an abruptly declining trend and subsequently continues constantly till 1980. From 1981, temperature showed an uneven pattern and the least minimum temperature $\left(18.96^{\circ} \mathrm{C}\right)$ was noticed in 1983 . Monthly temperature over decades indicated that maximum temperature of recent decade showed a decreasing trend during the month of December, January and March, while, it was slightly higher in the month of November and February compared to past decade (1995-2004) and base year (1970-1994). In contrast, minimum temperature revealed an increasing trend in most of the months though slightly decreased trend was noticed in the month of January compared to recent decade and base year (Figure 3). Temperature of current decade (2005-2015) showed an increasing trend (Figure 4) compared to past decade (1995-2005) and base year (1970-1994).

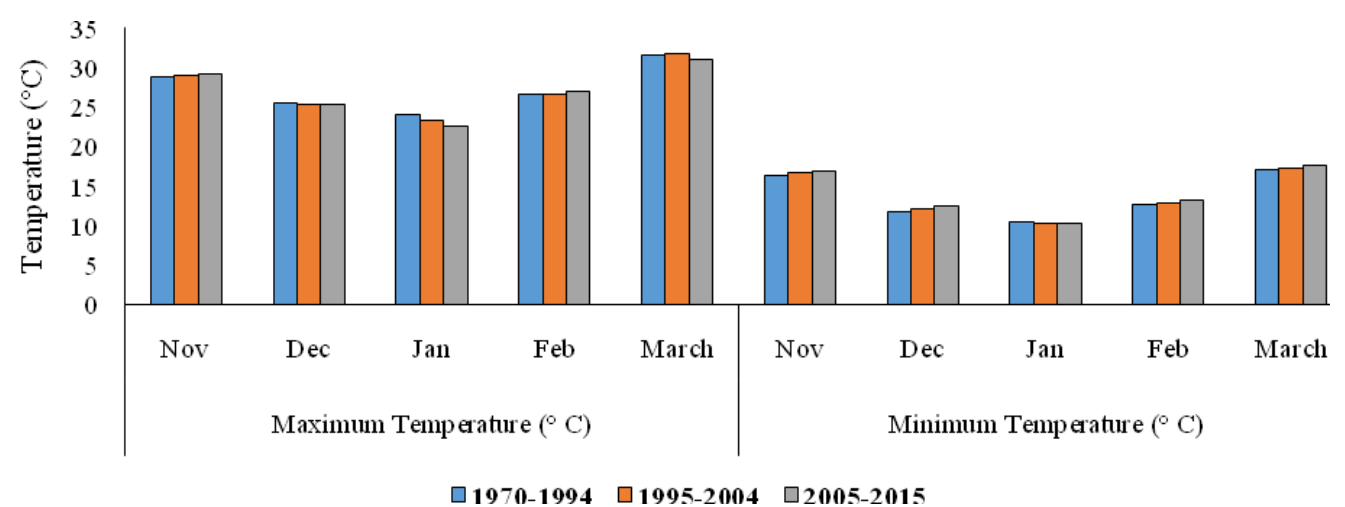

Figure 3. Variation of maximum and minimum temperature during the month of November to March over decades at the study area

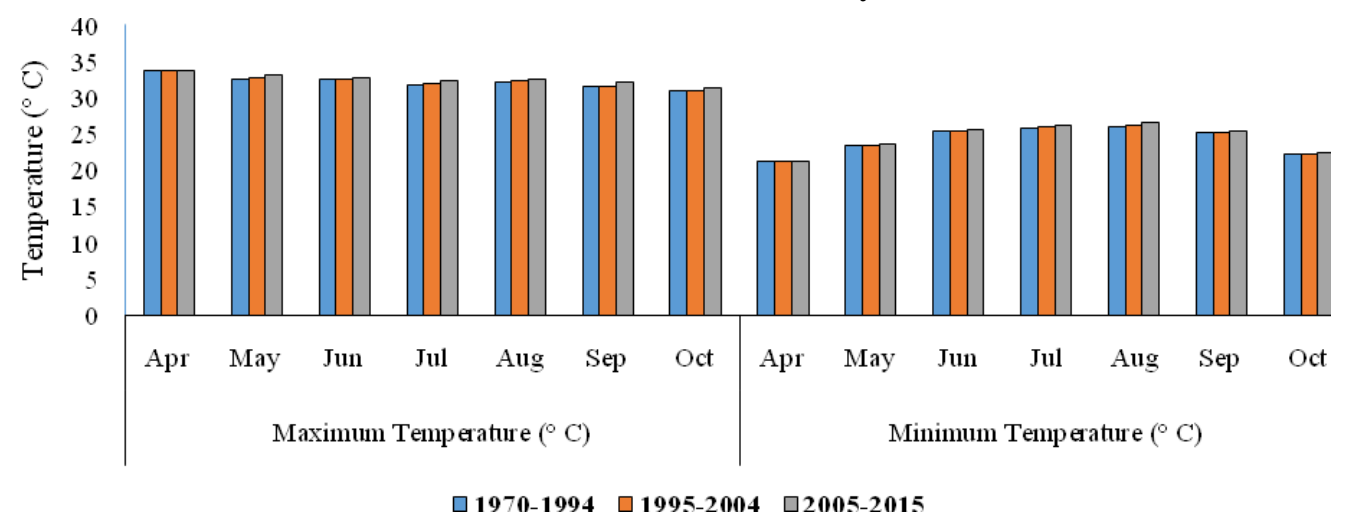

Figure 4. Variation of maximum and minimum temperature during the month of April to October over decades at the study area 


\section{Trend of rainfall and frequency of SPI}

The analysis of long-term rainfall database reflected that change of rainfall pattern was not definite over seasons. The long trend of annual rainfall indicated slightly increasing pattern in the study area (Figure 5) and the increment rate was $3.87 \mathrm{~mm}$ per decade. Nevertheless, from 1970 to 1980, rainfall showed a constant trend but afterwards the trend was somewhat irregular. The highest annual rainfall (3206 mm) was recorded in the year of 1987 and this was probably the causes for devastating flood. However, after that there was a decreasing pattern and reached the least value $(1142 \mathrm{~mm})$ in 1994 . After that annual rainfall again showed slightly increasing trend till 2006 and again demonstrated declining pattern. Regarding seasonal variation, mean monthly rainfall of recent decade was remarkably lower in most of the months (November to March) compared to past decade (Figure 6). On the other hand, base year (1970 to 1994) monthly rainfall showed an increasing pattern up to mid-January then sharply declined although again increased in the month of March but comparatively lower than recent decade (2005-2015). The decreasing trend of winter season rainfall is associated with higher rate of increase in minimum temperature (Wang et al., 2012) that might hampered the growth of the wheat crop. On the other hand, rainfall from April to October in recent decade showed almost decreasing trend but it was observed an increasing pattern in the month of June and October as compared to past decade and base year (Figure 7). The annual drought and wet frequency corresponding to SPI (Standardized Precipitation Index) in the study area has been shown in figure 8 . The result revealed that drought frequency was less dominant in the recent years and the SPI values doesn't crossed the normal level $(-0.5$ to +0.5$)$ in most of the years.

Nevertheless, after 1972, SPI value showed a constant trend to 1980, then after demonstrated uneven pattern and maximum SPI value was recorded in 1987, while lowest value in 1994 (Figure 8). Seasonal variation in weather parameters might have also increased the disease, insect and pest incidences in trees and crops as well as in other vegetation. A warmer climate with uncertain winter rainfall is likely to affect wheat production and also other winter crops.

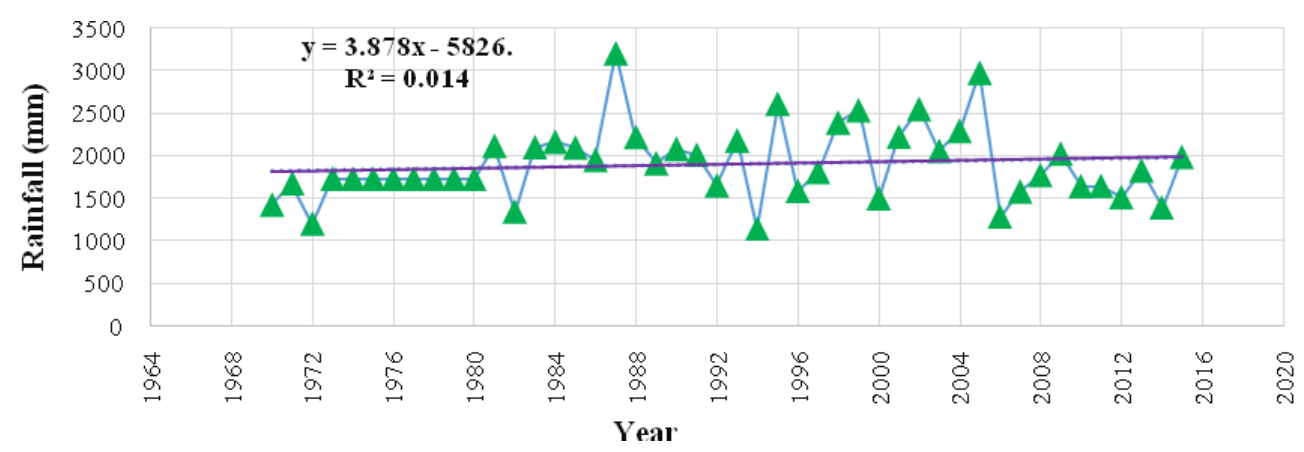

Figure 5. Longterm (1970 to 2015) trend of annual rainfall in the study area 


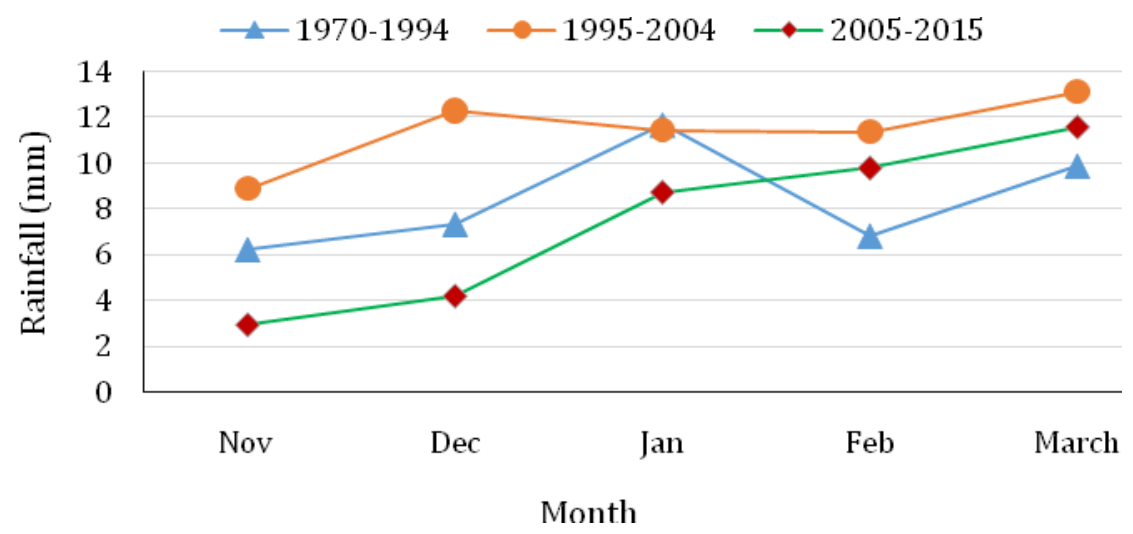

Figure 6. Variation of rainfall during the month of November to March over decades at the study area

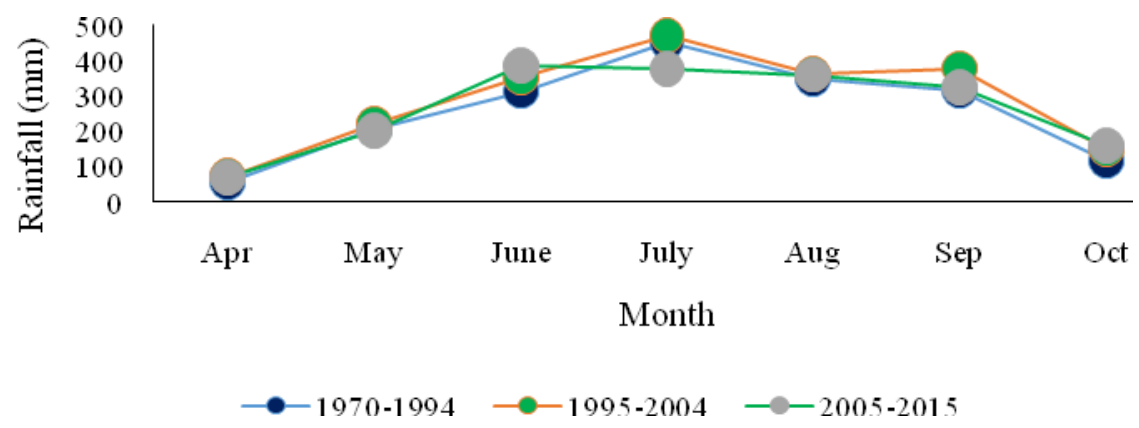

Figure 7. Variation of rainfall during the month of April to October over decades at the study area

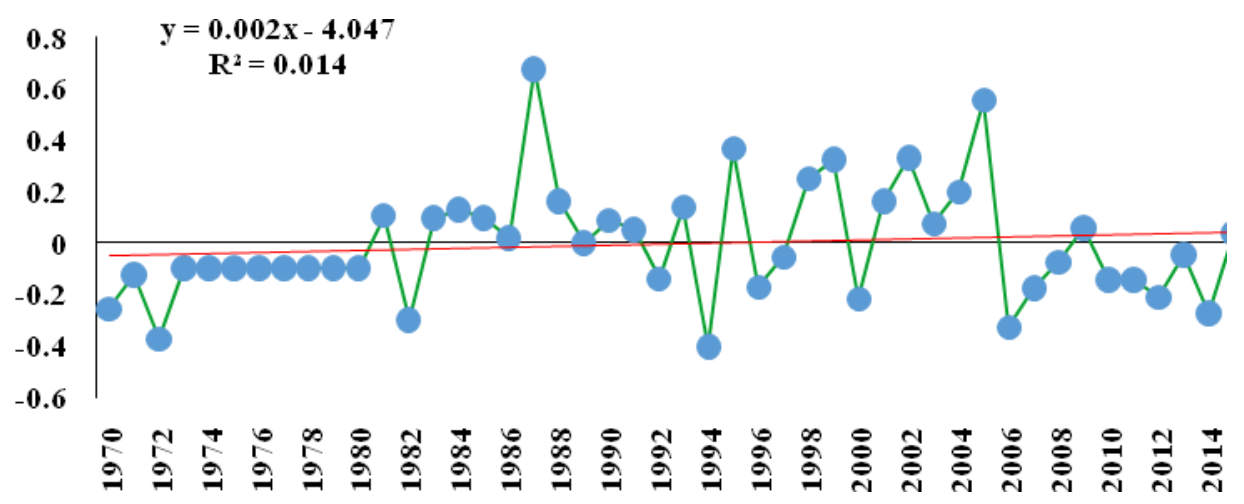

Figure 8. SPI values on rainfall data at the study area 


\section{Farmer's perception during wheat production season}

The perceptions of the community on change of local climate over time (10 -15 years ago) revealed that respondent perceptions (Table 1 and 2) were almost similar in many cases to the evidences of climate change recorded from the meteorological database. Regarding the change of temperature over time during wheat production season (November to March), $77.44 \%$ respondents opined that average temperature had increased while $18.05 \%$ participant opined that there was no change in temperature while, only $4.51 \%$ people had no opinion. Interestingly, no farmer reported that temperature was decreased in winter season. In contrast, during the month from April to October, $78.20 \%$ participant farmers opined that temperature had increased while only $3.01 \%$ farmer said that temperature decreased. On this issue, $12.78 \%$ and $6.02 \%$ participants told that temperature had no changes. This statement was also found consistent with the change of minimum temperature of long term database which stated that extent of summer season increased gradually over time.

\section{Rainfall}

Regarding rainfall (precipitation) intensity, during the month from November to March, approximately $6.77 \%$ farmer opined about increment of rainfall, while,65.41, 17.29 , and $10.53 \%$ opined as decreased, unchanged and no opinion, respectively. On the other hand, rainfall from April to October, 53.68\% farmer said that the rainfall was increased, whereas, $25.26 \%$ farmer said about decrease of rainfall. However, $14.29 \%$ farmer opined that rainfall was unchanged, while, $6.77 \%$ had no opinion. The findings of this study are almost similar to that of meteorological data base. Karttenberg et al. (1995) stated that the current assessment for Bangladesh by the IPCC (2007) predicts warming of $1.5-2.0^{\circ} \mathrm{C}$ by 2050 , with $10-15 \%$ increased rainfall by 2030 and a $12 \%$ increase in evaporation by 2030 .

\section{Availability of ground water}

Regarding the impacts of climate change on ground water status in the month of November to March, $40.10 \%$ farmer's opined depletion of ground water, while, $24.81 \%$ farmer said groundwater remained as it is in the past and $9.02 \%$ had no opinion on groundwater. Conversely, 50.43\% farmer said about increment of groundwater status in the month of April to October while $36.03 \%$ farmer opined ground water table goes down. However, unchanged ground water status was opined by $10.53 \%$ farmer, whereas, $3.01 \%$ had no opinion. The probable reason for decreased ground water status might be due to increased minimum temperature trend in winter season. Furthermore, installation of shallow tube well in the crop field also responsible for ground water depletion. However, increased rainfall in the month of April to October responsible for increased ground water status.

\section{Availability of surface water}

Surface water availability in the month of November to March was increased as reported by $29.00 \%$ farmers, whereas, decreased by $40.92 \%$ while, $21.80 \%$ farmer 
didn't observed any change of surface water status and $8.27 \%$ had no opinion. April to October, $66.69 \%$ farmer opined increment of surface water status while, $16.02 \%$ said surface water was decreased over time. Nevertheless, surface water was unchanged as opined by $13.53 \%$ farmer, whereas, $3.76 \%$ farmer had no opinion (Table 1). The increased trend of temperature augment evapo-transpiration rate which might be responsible for lessening of surface water availability in winter months.

\section{Drought}

Respondent opinion regarding drought condition during the month of November to March of the study area revealed that $41.61 \%$ people supported augmentation of drought, while, $33.53 \%$ farmer told decreased drought condition than that of past. Nonetheless, unchanged drought condition was opined by $21.10 \%$ farmers, whereas, $3.76 \%$ people had no opinion. On the other hand, information regarding drought situation in the month of April to October demonstrated that only $25.43 \%$ farmer said about increment of drought, whereas, $55.94 \%$ people opined decrease of drought. However, $11.21 \%$ people didn't observed any divergence of drought from the past, while, $7.42 \%$ had no opinion (Table 2). The study area faced moderate drought despite of profuse rainfall which might be due to uneven rainfall distribution, moreover, increasing of cropping intensity aggravate the drought situation. However, both meteorological database and community perception strongly supported the changes of climate variability of the study area over time. From the above findings, it was evident that changes of temperature hamper the production of wheat seriously alongside uneven rainfall triggering insect and pest infestation as well as decrease of ground and surface water resultant prolonged drought situation that had slowed but continuous adverse effects on wheat production. Siddique et al. (2000) found that drought stress significantly decreased the leaf water potential and relative water content of wheat, which had pronounced effects on photosynthetic rate. In drought, photosynthetic rates decreased with a decrease in stomatal conductance. Tolerant varieties were less affected than sensitive ones (Siddique et al., 1999).

Table 1. Respondents' perception on climate change over time (November to March) in the study area

\begin{tabular}{l|c|c|c|c}
\hline \multirow{2}{*}{\multicolumn{1}{c}{ Climatic variables }} & \multicolumn{4}{c}{ Respondents' perception (\%) } \\
\cline { 2 - 5 } & Increased & Decreased & Unchangeable & No opinion \\
\hline Temperature & 77.44 & 0.00 & 18.05 & 4.51 \\
Rainfall & 6.77 & 65.41 & 17.29 & 10.53 \\
Availability of ground water & 26.07 & 40.10 & 24.81 & 9.02 \\
Availability of surface water & 29.00 & 40.92 & 21.80 & 8.27 \\
Drought & 41.61 & 33.53 & 21.10 & 3.76 \\
\hline
\end{tabular}


Table 2. Respondents' perception on climate change over time (April to October) in the study area

\begin{tabular}{l|c|c|c|c}
\hline \multirow{2}{*}{ Climatic variables } & \multicolumn{4}{c}{ Respondent's perception (\%) } \\
\cline { 2 - 5 } & Increased & Decreased & Unchangeable & No opinion \\
\hline Temperature & 78.20 & 3.01 & 12.78 & 6.02 \\
Rainfall & 53.68 & 25.26 & 14.29 & 6.77 \\
Availability of ground water & 50.43 & 36.03 & 10.53 & 3.01 \\
Availability of surface water & 66.69 & 16.02 & 13.53 & 3.76 \\
Drought & 25.43 & 55.94 & 11.21 & 7.42 \\
\hline
\end{tabular}

\section{Climate change impacts on wheat cultivation}

Most of the farmers $(72.5 \%)$ said that climate change and climate variability issues had notable impacts on wheat cultivation in compare with $27.5 \%$ farmers who said that climate had no effects on wheat production. The below findings suggests that, due to close connection with wheat research centre (WRC) they are more aware about the devastating effects of climate change while some farmers may be live far away from the WRC hence they didn't avail up to date information.

\section{Adaption to combat climate change}

A Technology Adaption Index (TAI) was prepared and presented in table 3. The respondents were asked to give their opinion against 9 technologies which are suitable to combat climate change effect against three point scale (Strongly Agree, Agree and Disagree) with corresponding scores 2, 1, and 0. Then TAI was computed multiplying the scores with the number of respondents and presented as rank order. In table 3 indicates that majority of the respondents were strongly agree with that all the nine selected technologies were suitable to combat climate change effect. Based on their TAI Adoption that most of them were strongly agreed to use newly recommended varieties $(75.62 \%)$ followed by improve irrigation facilities $(71.25 \%)$, excavate mini pond $(66.87 \%)$, practice of zero tillage (61.87\%), up scaling of agroforestry $(54.37 \%)$, management of orchard $(57.50 \%)$, early planting and harvesting $(55.00 \%)$, use FYM (51.87\%), and late planting (47.50\%). Adoption of new varieties and irrigation facilities rank first and second position to combat climate change effect on wheat production (Table 3 ). 
Table 3. Adoption technologies to combat climate change effect on wheat production

\begin{tabular}{lc|c|c|c|c}
\hline \multicolumn{1}{c|}{ Adaption technologies } & Strongly Agree & Agree & Disagree & TAI & Rank \\
\hline $\begin{array}{l}\text { Adoption of new varieties in farming } \\
\text { practices }\end{array}$ & $121(75.62)$ & $34(21.25)$ & $5(3.12)$ & 276 & 1 \\
Early planting and harvesting & $88(55.00)$ & $38(23.75)$ & $34(21.25)$ & 214 & 7 \\
Late planting & $76(47.50)$ & $38(23.75)$ & $46(28.75)$ & 190 & 9 \\
Irrigation facilities & $114(71.25)$ & $37(23.13)$ & $9(5.62)$ & 265 & 2 \\
Zero tillage & $99(61.87)$ & $34(21.25)$ & $27(16.87)$ & 232 & 4 \\
Farm yard manure (FYM) preparation & $83(51.87)$ & $39(24.37)$ & $38(23.75)$ & 205 & 8 \\
Orchard management & $92(57.50)$ & $38(23.75)$ & $30(18.75)$ & 222 & 6 \\
Agroforestry management & $87(54.37)$ & $51(31.87)$ & $22(13.75)$ & 225 & 5 \\
$\begin{array}{l}\text { Excavation of Mini Ponds for } \\
\text { supplemental irrigation }\end{array}$ & $107(66.87)$ & $36(22.50)$ & $17(10.62)$ & 250 & 3 \\
\hline
\end{tabular}

Parenthesis indicates \% of respondents

\section{CONCLUSION}

Climate change is a burning issue of the world. Based on the findings it can be concluded that, analysis of long term meteorological data of the study area showed a steadily changing scenario of climate over time, where minimum temperature has been increased at the rate of $0.009^{\circ} \mathrm{C}$ per year, while maximum temperatures has been slowly decreased at the rate of $0.004^{\circ} \mathrm{C}$ per year. The trend of annual rainfall indicated an increasing rate was $3.87 \mathrm{~mm}$ per year. On the contrary, the mean monthly rainfall of recent decade during the month of November to March showed a decreasing pattern resulting more dry period in winter season. The winter and summer temperature had increased as opined by 77.44 and 78.20 percent farmers, respectively. Regarding rainfall (precipitation) intensity, majority of the respondents opined that the rainfall intensity had decreased in winter season (November to March) but increased in summer season (April to October) over time. Regarding the water availability, majority of the respondents expressed that surface and ground water levels have declined in winter season while increased in summer season which was very much consistent with the current climatic events.

Farmer's opinion regarding suitable technology to combat climate change impact on wheat production revealed that use of newly recommended varieties. In addition, farmers opined that WRC should provide more quality seed, training program and maintain regular contact with the farmers. The above findings suggested that the farmers were become aware and possess favorable response towards curtailing climate change impacts. The author suggested that the long term field trial 
on improved varieties of wheat with close monitoring on yield attributes influenced by changes of weather parameters such as temperature and rainfall are needed.

\section{REFERENCES}

Agrawala, S., Ota, T., Ahmed, A. U., Smith, J. and Van Aalst, M. 2003. Development and climate change in Bangladesh: focus on coastal flooding and the Sundarbans. OECOD, France

Ahmed, A. U. and Alam, M. 1999. Development of climate change scenarios with general circulation models. In Vulnerability and adaptation to climate change for Bangladesh. pp. 13-20. Springer Netherlands

Ahmed, A. U. 2006. Bangladesh Climate Change Impacts and Vulnerability. A Synthesis; Climate Change Cell, Department of Environment, CDMP, Government of the People's Republic of Bangladesh, Dhaka, Bangladesh

Amin, M. G. M., Ali, M. H. and Islam, A. K. M. R. 2004. Agro-climatic analysis for crop planning in Bangladesh. Bangladesh Journal of Agricultural Engineering, 15(1): 1-40

Bangladesh Bureau of Statistics (BBS). 2005. Compendium of Environment Statistics of Bangladesh. Government of Bangladesh, Dhaka, Bangladesh

Basak, J. K., Ali, M. A., Islam, M. N. and Alam, M. J. B. 2009. Assessment of the effect of climate change on boro rice production in Bangladesh using CERES-Rice model. In Proceedings of the international conference on climate change impacts and adaptation strategies for Bangladesh. pp. 103-113

Ferdous, M. G. and Baten, M. A. 2011. Climatic variables of 50 years and their trends over Rajshahi and Rangpur Division. Journal of Environmental Science and Natural Resources, 4(2): 147-150

Food and Agriculture Organization. 2007. Climate Variability and Change: Adaptation to Drought in Bangladesh. In A Resource Book and Training Guide; FAO: Rome, Italy

Government of Bangladesh (GOB) and United Nations Development Program (UNDP). 2009. The Probable Impacts of Climate Change on Poverty and Economic Growth and Options of Coping with Adverse Effects of Climate Change in Bangladesh. Policy Study, Dhaka, Bangladesh

Hossain, A. and Da Silva, J. A. T. 2013. Phenology, growth and yield of three wheat (Triticum aestivum L.) varieties as affected by high temperature stress. Notulae Scientia Biologicae, 4(3): 97

IPCC (Intergovernmental Panel on Climate Change). 2007. Climate change 2007. Synthesis Report. Contribution of Working Groups I, II and III to the Fourth Assessment Report of the Intergovernmental Panel on Climate Chang [Core Writing Team, Pachauri RK, Reisinger AJ, eds]. Geneva, Switzerland: IPCC, 104

Karttenberg, A. F., Giorgi, H., Grassl, G. A., Meehl, J. F. B., Mitchll, R. J., Stouffer, T. and Wigley, T. M. L. 1995. Climate models-projection of future climate

Mirza, M. M. Q. 1997. Modeling the Effects of Climate Change on Flooding in Bangladesh. Ph.D. Thesis, International Global Change Institute (IGCI), University of Waikato, Hamilton, New Zealand 
Sarker, M. A. R., Alam, K., and Gow, J. 2012. Exploring the relationship between climate change and rice yield in Bangladesh: An analysis of time series data. Agricultural Systems, 112: 11-16

Siddique, M. R. B., Hamid, A. and Islam, M. S. 1999. Drought stress effects on photosynthetic rate and leaf gas exchange of wheat. Botanical Bulletin of Academia Sinica, 40

Wang, L., Li, J., Lu, H., Gu, Z., Rioual, P., Hao, Q. and Han, J. 2012. The East Asian winter monsoon over the last 15,000 years: its links to high-latitudes and tropical climate systems and complex correlation to the summer monsoon. Quaternary Science Reviews, 32: 131-142

World Bank. 2013. Bangladesh Poverty Assessment: Assessing a Decade of Progress in Reducing Poverty, 2000-2010. Bangladesh Development Series Paper No. 31 